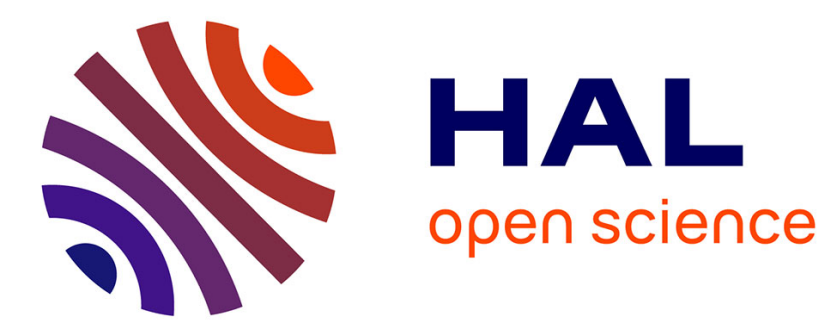

\title{
Policing and Gender in France
}

Mathilde Darley, Gauthier Jérémie

\section{To cite this version:}

Mathilde Darley, Gauthier Jérémie. Policing and Gender in France. Policing in France, 2021. halshs03293639v1

\section{HAL Id: halshs-03293639 https://shs.hal.science/halshs-03293639v1}

Submitted on 21 Jul 2021 (v1), last revised 25 Aug 2021 (v2)

HAL is a multi-disciplinary open access archive for the deposit and dissemination of scientific research documents, whether they are published or not. The documents may come from teaching and research institutions in France or abroad, or from public or private research centers.
L'archive ouverte pluridisciplinaire HAL, est destinée au dépôt et à la diffusion de documents scientifiques de niveau recherche, publiés ou non, émanant des établissements d'enseignement et de recherche français ou étrangers, des laboratoires publics ou privés. 
$<$ BOOK-PART $><$ LRH $>$ Mathilde Darley and Jérémie Gauthier $</$ LRH $>$

$<$ RRH $>$ Policing and Gender in France $</$ RRH $>$

$<$ BOOK-PART-META $><$ LBL $>\mathbf{1 9}</$ LBL $>$

$<$ TITLE $>$ Policing and Gender in France $</$ TITLE $></$ BOOK-PART-META $>$

$<$ OPENER $><$ CONTRIBS $><$ AU $><$ GNM $>$ Mathilde $</$ GNM $><$ SNM $>$ Darley $</$ SNM $></$ AU $>$ and $<$ AU $><$ GNM $>$ Jérémie $</$ GNM $><$ SNM $>$ Gauthier $</$ SNM $></$ AU $></$ CONTRIBS $>$

\section{$<$ ABSTRACT $><$ TITLE $>$ Abstract $</$ TITLE $>$}

This chapter documents the role that gender norms play in strategies for establishing one's professional identity within the police. It is based on several years of fieldwork carried out within the police force, including an ethnographic study undertaken by a two-person male/female team. We consider in parallel the gendered structure of the policing profession and the character of interactions between officers and the public. Resistance to the feminization of police units can be linked to officers' gendered representations of the populations they deal with, as well as by sociability within the organization. The dominant masculinity which molds police professional identity is understood here as a complex entanglement of attributions based on gender, sexuality, and race. $</$ ABSTRACT $>$

\section{$</$ OPENER $>$}

$<$ BODY > The 1983 film Faits divers, directed by French documentary film-maker Raymond Depardon, unveiled the daily life of a police station of the 5th arrondissement in Paris. It was an exclusively male professional environment, organized around virile sociability, in which women, when they did appear, could only aspire to victim status. ${ }^{1}$ In the early 1980 s, policing in France was still "a man's job" and the recent and modest opening up of the profession to women had not yet disturbed this male monopoly. However, as the rhetoric of state "modernization" developed, profound transformations, including the feminization of the workforce, were under way in a certain number of public organizations. Over the following decades, goals of gender equality and the spread of egalitarian norms - inspired by the UKand US-led "diversity" framework (Bereni and Jacquemart 2018) and associated with the paradigm of the "fight against discriminations" (Fassin 2002) - became an issue of legitimacy for a number of public and private organizations. The police institution, having already undergone numerous attempts at transformation (Jobard and de Maillard 2015), was a prime candidate for this reforming trend.

Nonetheless, the police were generally described in studies as particularly resistant to change, due to a so-called "police culture" uniting its members. In particular, it was said to possess, as other organizations, a uniquely "gendered substructure" (Acker 1990), where the 
"cult of masculinity" (einer 2000) was a pillar of police identity (Fielding 1994;

Heidensohn 1992; Hunt 1990; Waddington 1999). Indeed, as of the 1990s, a number of studies of policing highlighted that the police organization was not "gender neutral" (Acker 1990), because the police culture and the exclusively male community it promoted had substantially encouraged and justified the exclusion of women (Westmarland 2001, p. 8). Described as "naturally" more vulnerable, physically and psychologically, than their male colleagues, women were supposedly incompatible per se with police work involving danger and "macho culture" (Heidensohn 2008). The development of the fields of law and public order seems thus to have greatly contributed to "preserving masculinity" and to slowing women's access to the policing profession, but also the ability of the police to accept and work with gender (Brown 2007).

The opening of law enforcement careers to women in most Western countries as of the 1970s therefore constitutes an "unprecedented anthropological event" (Pruvost 2008). It was a response to the demands of certain feminist groups, but also to a legitimacy crisis within the institution, which, it was hoped, could be alleviated at least in part by the feminization of the workforce. However, this opening was soon marred by the numerous reports pointing to discrimination against women having entered the police force (Silvestri 2003, p. 30). Those findings encouraged British and American social scientists to question the effects of the cult of masculinity on internal relations among police officers (Burke 1993), but also on the relationship between police officers and the public. For a long time, however, French studies on the police paid only marginal attention to gender as "a bi-categorization system based on a hierarchy between sexes (men/women) and between the values and representations associated with them (masculine/feminine)" (Bereni et al. 2008, p. 7). A parallel can be drawn between this observation and two other conditions. First, the long invisibility of gender in French social sciences (Le Feuvre et al. 2013) - particularly in the sociology of policing - and French organizations, especially public ones (Marry et al. 2017). Second, the policing model prevalent in France is based on a hierarchical view of power relationships that glorifies authority. It is marked in addition by the singular importance given to tasks that are perceived as "virile," because they require the use of force in the fight against crime. This is to the detriment of administrative or preventive duties, which are stigmatized as "social work" (Darley and Gauthier 2014).

The gender division found in police work being partly mirrored in sociological work, research on the French police remained, until the mid-2000s, an almost exclusively male field (Lévy 1987; Monjardet 1996). This probably accounts for the "gender blindness" of the 
research it produced. The male domination prevailing in the police world seems to have long been taken for granted, without being the subject of specific questioning by the male ethnographers of the institution. And yet, the late and unprecedented feminization of the institution, and the gender bias observable in the selection of police targets (and subsequently reflected in all branches of the criminal justice system), might well have attracted the attention of researchers. Not until the end of that decade did the first women-led field studies in different police units begin to flourish (Lemaire 2008; Mainsant 2008; Proteau and Pruvost 2008; Pruvost 2007a, 2007b; and more recently: Guenot 2018; Morelle 2017; Pérona 2017). These studies were conducted mainly within the street policing and criminal investigation departments. A number of these studies helped bring to light the impact of sex and gender on policing, be it in "the gendered allocation of patrols ... or the disruption of the power relations between (majority) male and (usually minority) female colleagues" (Pruvost 2007b). Research also revealed the gendered division of labor that excludes women from the most noble aspects of police work (Boussard et al. 2007; Mainsant 2014). There was research on their interactions with target populations and the handling of so-called "gender" violence (Pérona 2017; Mainsant 2012), and on the effects of police stereotyping regarding colonized populations (Blanchard 2008, 2012). The feminization of research into the police thus seems to have been, at least in part, a necessary condition for documenting gender norms in the policing world.

In line with these studies, this chapter documents that gender norms play a key role in strategies for establishing one's professional identity in the police force. Additionally, it illustrates that an ethnographic study carried out by a two-person male/female research team, conducted precisely within an institution where "norms, procedures and organizational culture are [particularly] marked by gender bias" (Bereni et al. 2008, p. 140), is able, by observing "gender in action" (Westmarland 2001, p. 12), to make its impact particularly salient. This unique research relationship seems to have facilitated the identification of situations revealing how gender is implicit in police work. This made it possible to then question the inclusion of dominant gender norms on a continuum that shapes police sociability, the relationships between police officers and citizens, and also the gendered aspect of the relationship between the ethnographers and the subjects of their study. Thus, we intend to contribute to showing how, despite the feminization of the institution, the "gender system" (Rubin 1975) constructed within the police institution rests on the reiteration of stereotypes that confirm virile masculinity as the dominant professional reference point. 
To do this, we will first consider in parallel the gendered structure of the policing profession and the order of the interactions between police officers and the public. The resistance to the feminization of police units can be linked to police officers' gendered representations of the populations they deal with. We will then attempt to articulate these gender norms and sexual norms, showing how the dominant gender in the institution is rooted in the supremacy of masculine heterosexuality. Finally, we call into question models of "normal sexuality" that are promoted in the police institution in general, and in units in charge of sexual offenses in particular.

\section{$<$ HEAD $1><$ TITLE> Policing: It's a "Man's Job"²</TITLE $></ H E A D 1>$}

$<$ DISP-QUOTE $>$ You shouldn't bring too many women in, one or two is enough: it's handy in some cases, like in surveillance operations, a bloke is less careful when he's being followed by a woman, or when some people only want to talk to a woman. But if we got to $50 \%$ of women, we'd lose some of our image. I'm aware that's misogynous, but we're not social workers: when we intervene, it's got to be ship-shape and when it's got to hurt, it's got to hurt. If you ask me, we have to keep that, the big cars, the tough guys, all that. In the end it's the arrest we're after, whether it's caught in the act or whatever, so there needs to be that fear; we're hunters, in a way.

$<$ ATTRIB $>$ (Male officer, crime squad, 3 July 2014) $</$ ATTRIB $></$ DISP-QUOTE $>$ Most of the men we interviewed in units specializing in the use of force (such as the Brigades Spécialisées de Terrain, ${ }^{3}$ the Compagnies de Sécurisation, ${ }^{4}$ and the Brigades Anti-Criminalité ${ }^{5}$ ) were also opposed to the feminization of their units, which was said to threaten the credibility of officers whose professional legitimacy is in large part founded on their ability to use physical force. The gradual entry of women into the police from the mid-1970s (Pruvost 2008) has not, then, succeeded in reversing the tendency for this to be a primarily male world. The modest feminization of the workforce that has occurred has, for the most part, come in units in which the potential use of force is not an issue. In 2017, women made up 79\% of the workforce in the administrative branch of the police, $61 \%$ in the scientific branch, but only $22 \%$ of field operatives. In this last group, women made up $27 \%$ of the commissaires (or superintendents) and $25 \%$ of the commanding officers, but only $20 \%$ of police constables (Ministry of the Interior 2017). This discrepancy can be attributed in equal measure to the scarcity of female candidates for constabulary-level entry tests and the higher "entrance fee" demanded by recruiters, who value candidates who can demonstrate their ability to "conform to the rules of a virile model that remains dominant within the institution" (Gautier 2018). The proportion of women in riot police units (such as the CRS - Compagnie Républicaine de Sécurité) barely 
exceeded $3 \%$ in 2018, excluding administrative staff. ${ }^{6}$

In the police station where we carried out our research, we also found that it was in

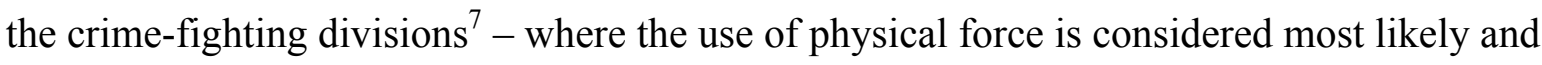
an inherent part of what defines the mission and prestige of the department - that the fewest women were to be found. ${ }^{8}$ These division departments are further characterized by their promotion of a hegemonic model of masculinity, one associated with the ability to demonstrate one's physical strength and aggressiveness (Connell 1987). This legitimizes the warrior-male, "rogue-hunter" type as the dominant professional identity.

$<$ DISP-QUOTE $>$ You've got to be tough, you can't lose eye contact, or you lose ground. Back when we had a monopoly in the poor neighborhoods, we had to be feared. When we turned up, we wanted the guys to be shitting themselves. You've got to feed that cowboy image a bit, even if it is a bit of a caricature. The tough guys from the crime squad, that has a psychological impact. We play on that; we know we're putting on a front. People on the outside say, "those crime squad cowboys, they're so full of themselves ..."

$<$ ATTRIB $>$ (Male officer, crime squad, 3 July 2014) $</$ ATTRIB $></$ DISP-QUOTE $>$ It follows that men working within units specialized in the use of force are more inclined to accept women colleagues who opt for a virilization of their behavior - those they can "consider as blokes" because "they’ve got brawn" (Male officer, crime squad, 2 July 2014). To avoid "blurring genders," however, those women are also expected to uphold certain attributes traditionally associated with femininity. Consequently, women police officers, whose place within the institution depends first and foremost on being appreciated (including in a sexual sense) by their male colleagues, have a delicate part to play in embodying their gender. They must be neither precious nor pretentious nor, worse still, "tomboys" or "lesbians" (Field journal, Compagnie de Sécurisation, December 2013). Above all, "women colleagues," if they want to "make a place for themselves" (in the words of one of our informants), must not introduce any fundamental changes to the gender order prevalent within the police institution. The rare women who have entered units specialized in the use of force therefore put in place strategies to distinguish themselves from their female colleagues, whose absolute physical and psychological alleged incompatibility with police work they reiterate. In so doing, they take up one of the main assertions of the hegemonic masculinity model, legitimizing the exclusion of women from the police profession because of their alleged lack of physical strength which makes them more vulnerable to "danger" (Silvestri 2003, p. 34). 
$<$ DISP-QUOTE $>$ I don't stand back and wait for the job to get done, I'm more of a leader, I try to be there and keep tempers down. You've got to have a strong personality and be in good shape. If you have to run, you've got to be able to run. I get on really well with the boys, I like that they speak frankly, women are much more underhand ... We can't start patrolling with two girls and one guy, you've got to be reasonable, we don't have the same physical abilities, or even the confidence, sometimes ..."

$<$ ATTRIB $>$ (Woman officer, crime squad, 20 November 2013) $</$ ATTRIB $></$ DISP-

To "play their part" in the police and, a fortiori, within units specializing in the use of force, women officers themselves actually contribute to reiterating gender stereotypes. By naturalizing differentiated female abilities, they justify the ineluctably subordinate position of women officers in the fight against delinquency and thereby, their own status as "outsiders" in the institution (Brown and Heidensohn 2000). Professional stereotypes associated with the female gender have to do not only with appearance, ${ }^{9}$ but also with women's supposed predisposition to take on certain tasks, such as "vice and juveniles" (Field journal, Compagnie de Sécurisation, 16 November 2013), because of the "emotional involvement" they imply (Pierce 2003). Pre-empting this, women police officers generally try to distance themselves from such gendered assignments, to set themselves apart from the "social worker," a figure unanimously rejected within the police institution. In so doing, they reproduce the gender stereotypes at work within the institution. Thus, women confirm this gendered organization of police tasks that, by opposing "social work" and "crime-fighting," contributes to define the codes of the profession and to confine women to the "feminine" construct of the administrative and emotional worlds, while their male counterparts, on the contrary, maneuver in a world of action and danger (Hunt 1990, p. 15).

\section{$<$ HEAD $1><$ TITLE $>$ Sexist Machos: The Targets of Police Action ${ }^{10}</$ TITLE $></ H E A D 1>$}

Recent debates in France around issues of police profiling focused mainly on the racial biases in police checks (DDD 2017; Fassin 2011; Jobard et al. 2012; see also Chapter 13 in this volume). However, statistically, the greatest disproportion is not in the race of those stopped but their gender. At the start of the decade, a survey carried out by questionnaire in Grenoble and Lyons on a sample population of 13,500 adolescents showed that $31 \%$ of boys had already been stopped by police, versus only 14\% of girls (Astor and Roché 2013, p. 102). Paralleling this, an observational study carried out in several Paris metro and train stations showed that, all other things being equal, a young white woman was between three and seven times less 
likely (depending on the location) than a young white man to be stopped by police (Jobard et al. 2012). More recently, a questionnaire-based survey confirmed, in 2016, that men were stopped more often than women (23\% of men versus $10 \%$ of women had been stopped in the previous five years (DDD 2017, p. 12). While a 2017 study of a representative sample of the French mainland population revealed that $38 \%$ of the men surveyed had been stopped once or more in the two years preceding the study, versus only $24 \%$ of women. ${ }^{11}$ Gender therefore acts as a filter for the populations to be targeted by the police. In turn, this leads to an underrepresentation of women among those people arrested. Indeed, a quantitative two-year study at a police station in a so-called "sensitive" Parisian banlieue showed that women made up little more than $7 \%$ of all those brought in to the station (Gauthier 2012, p. 193). These statistics confirm that the police client base, especially in the case of police-initiated contacts with police (i.e. checks and arrests) as opposed to contact initiated by the public (in the form of complaints or calls for help), is predominantly male.

Our ethnographic study reveals certain statistically proven aspects of this gendered selection, while situating it in the broader professional context in which it occurs. Indeed, in "crime-fighting" work, police focus their attention almost exclusively on men, and in particular on the supposedly dangerous figure of the "banlieue youth." His supposed "origin," deduced from his physical appearance and compounded by the stigma of residence is a banlieues, is associated with an increased likelihood to commit acts of delinquency - and so justifies frequent checks (DDD 2017; Fassin 2011; Jobard et al. 2012; Chapter 13 in this volume). As one officer noted to us, “In some cultures, women don't occupy a very good position and we see those cultures more in the rough neighborhoods than elsewhere" (Woman officer, crime squad, 3 July 2014).

The characteristics assigned to "banlieue youths" by police officers are therefore grounded on overlapping stereotypes of class ("rough neighborhood"), race ("in some cultures," generally referring indiscriminately to North Africans and Muslims), and also gender ("women don't occupy a very good position"). Those social and racial attributions are indeed associated with a particular gender identity. From these stem a discourse indicating that street policing is a "man's job," which rests for the main part on the emphasis put on the supposed machoism of young men from working-class neighborhoods and on the virile confrontation which is consequently inherent in any interaction with them. 
Policewoman: Yes. But my Sarge doesn't want me to, he says it's just not done. But in reality, when we stop and search 15 guys and there are only five of us, I'm not going to stand there looking at them, so I'll frisk one or two. That said, all the North African guys, they really don't like being frisked by a woman, mind. They don't even look you in the eye, they don't want to talk to a woman, most of them, it's pretty crazy, they don't like it one bit ... So, in those cases, I'm careful with the North African guys, because it can lead to clashes because they get so pissed off that they get angry and it can cock up the whole operation. So, I avoid frisking men as much as possible, unless it really can't be helped.

$<$ ATTRIB $>$ (Woman officer, crime squad, 17 April 2004) $</$ ATTRIB $></$ DISP-

QUOTE>

In conflictual interactions, sexism can be used as a resource by people that police officers try to submit to forced procedures, such as ID checks, searches, and frisks. This in-situ questioning of the legitimacy of woman police officers by their clients, and the fact that their presence alone can be a hindrance to police imposing their authority, leads to a weakening of their position relative to their male colleagues while also preventing them from carrying out certain tasks which are particularly common in crime-fighting units (such as a frisk or an ID check). These observations illustrate how the marginalization of women in the policing world and in the street culture of the working-class neighborhoods (Mohammed 2009) mirrors the virile constructs inherent to both those spaces. The glorification of the "real power struggle with the guys in the rough neighborhoods" (Male officer, Compagnie de Sécurisation, 16 November 2013) thus leads officers to favor male targets. Indeed, the inability to use (or threaten to use) force on "girls" seems to rob crime squads of one of their main status symbols:

$<$ DISP-QUOTE $>$ Researcher: Is it unthinkable for a male officer to slap a girl?

Policeman: Oh, yeah, utterly unthinkable. A female colleague can get physical, get close up. With blokes, if I get up close, I'm going to follow through and I might slap him if needs be, whereas, with a girl, if I move in on her ... Well, it's not to back right off again!

$<$ ATTRIB $>$ (Interview, male officer, crime squad, 2 July 2014) $</$ ATTRIB $></$ DISP-

In other words, the lesser legitimacy of women conducting certain police jobs, particularly in units emphasizing the use of force, is explained not so much by the norms, values, or professional practices of those units. Rather, it is occasioned by the personal characteristics not only of the women themselves, but also of the targets of police action. These are the "sexist 
machos" who "naturally" offer less resistance to male officers.

\section{$<$ HEAD $1><$ TITLE $>$ Sexuality as the Organizing Principle for Gender \\ Order $</$ TITLE $></$ HEAD $1>$}

Our focus on the gendered structure of policing led us also to note the importance of norms associated with sexuality in the construction of the gender identities prevailing in the institution. First, while the supremacy of heterosexuality contributes to maintaining gender order in relationships between colleagues, the growing visibility of homosexuality among personnel contributes, at least in part, to eroding that order. Second, the analysis of police tasks specifically dedicated to policing sexual offences at first also seems to lead to the observation that gender norms hinging on the virile male stereotype have been partially challenged. Nevertheless, it ultimately confirms the role of sexuality as one of the main instruments for reaffirming a hegemonic heterosexual masculinity within the police institution.

\section{$<$ HEAD2 $><$ TITLE $>$ Hierarchies of Intimacy in Police Sociability $</$ TITLE $></$ HEAD2 $>$}

The preservation of a gender order within policing rests not only on the perpetuation of a masculine identity which glorifies physical strength, but also on a hierarchy of sexes and sexualities that is reflected in the many references to officers' marital relations. Jokes are often

made about male officers living with a partner, and they tend to highlight the incompatibility between the professional identity and job demands of being a police officer and any kind of commitment to domestic life. Wives or partners are represented as posing a threat to the officer's masculinity, through their attempts to drag him to into home and family:

$<$ DISP-QUOTE $>$ You've been bloody had, you didn't want to move in, you moved in, you didn't want to buy the flat, you bought the flat, you didn't want the civil partnership, you got the civil partnership, you don't want kids ... just you wait and see, you'll be done for!

$<$ ATTRIB $>$ (Field journal, crime squad, 4 July 2013) $</$ ATTRIB $></$ DISP-QUOTE $>$ Such reminders of gender order, which make the world of policing an almost perfect illustration of hegemonic masculinity (Fielding 1994), also reaffirm differentiated gender roles. They imply, in a very traditional sense, the need for men to demonstrate their "heterosexual desire" and for women, their "sexual reserve" (Clair 2013, p. 113).

$<$ SPEECH $><$ SPEAKER $>$ Researcher $</$ SPEAKER $>$ : There's a lot of talk about "rubbing elbows" with friends in other divisions to exchange info. Do you have your own little network of colleagues, too? $</$ SPEECH $>$ 
$<$ SPEECH $><$ SPEAKER $>$ Policewoman $</$ SPEAKER $>$ : No, no. I value my colleagues in the department, but I avoid being too friendly, on the other hand, precisely because I'm a woman and there's a certain distance that I want to keep. I'm not going to go and rub elbows elsewhere to get into such-and-such a department ... I wouldn't want people thinking that I'm using my charms for any network. I wouldn't want it to be seen as seduction, so I just avoid it. I am actually super reserved as far as that goes.

(Interview, woman police officer, Police rescue, 22 May 2013) $</ \mathrm{SPEECH}>$ Networking among staff is frequently described as essential for the exchange of information related to investigations, as well as for promotion to more highly valued divisions (Darley and Gauthier 2014; Mainsant 2014). But we can see here that gender, as one aspect of organizational structure, shapes officers' experience by "imposing different normative expectations for male and female workers" (Pierce 2003, p. 57) and, more importantly, by “setting limits on women's behavior" (Pierce 2003, p. 66). These calls to order are all the more significant because they occur in a professional context which is already marked by the oversexualization of sociability, where sexual or sexist jokes and bragging about one's (hetero)sexual performance are considered essential attributes for displaying police masculinity. Thus, sexuality appears to continue to function within the police institution as an organizing principle of a heterosexual hierarchy, one that "institutes what is normal [and] classifies social actors", but also "disqualifies ... deviants" (lair 2016, p. 53).

One might suppose that the dominance of heterosexuality in police sociability and in the definition of police target groups would begin to wear thin in the contemporary context, which is one of the "softening of social and legal obligations having long weighed on homosexual minorities" (Giraud 2016). Indeed, since homosexuality was decriminalized in the early 1980s, homosexuals are no longer targeted groups (Gauthier and Schlagdenhauffen 2019a; Jaouen 2017; Tamagne 2000). The mobilization of the gay community and the introduction of anti-discrimination legislation have contributed to transforming the role of the police and the law regarding the LGBTQ population. Opposition to homosexuality has gradually given way to rejection of homophobic discrimination and violence. In parallel, there has been a mobilization of LGBTQ police officers since the $2000 \mathrm{~s}$, in line with what can be seen in US- and UK-based organizations. This gives visibility to gay, lesbian, bi- and transsexual police officers, and allows them to denounce homophobia in their profession and claim the same rights as their heterosexual colleagues. The sustained effects of these changes on the "heterosexual hierarchy" are not yet clear. However, the first results of investigative interviews carried out between 2015 and 2019 with police officers describing themselves as 
gay, lesbian, or bisexual, indicate that conforming to heterosexual norms continues to be a condition for establishing a legitimate professional identity (Gauthier and Schlagdenhauffen $\underline{2019 b)}$.

\section{$<$ HEAD $1><$ TITLE $>$ Policing Sexual Offenses: A Gendered Job $</$ TITLE $></ H E A D 1>$}

Sexuality appears to be one of the main instruments confirming hegemonic heterosexual masculinity within the police institution. Consequently, it is interesting to test these observations within divisions dedicated to policing matters related to sexuality. These include the Brigade des mœurs (or Vice Squad) and the Brigade des mineurs (or Juvenile Crime Squad), units that deal with sexual violence against adults and young people. ${ }^{12}$ Indeed, sexual norms within divisions whose core work involves the handling of sexual offences do seem to differ from those prevailing within policing generally. The mours and mineurs units provide valuable insights in this respect. Use of force by members of these units is almost non-existent, and the typical street policing identity - defined by the unspoken link between "physical strength" and "being male" - is not the prevalent model.

$<$ DISP-QUOTE $>$ I'm more intellectual than manual, and I prefer to work in an office than be chasing people around. I only go to the firing range because I have to, it's not my cup of tea ... In here, you need to have a more psychological approach to people. $<$ ATTRIB $>$ (Male officer, Brigade des mœurs, 12 February 2014) $</$ ATTRIB $></$ DISP-

The mæeurs and mineurs units occupy a unique position in the hierarchy of police jobs. Officers from other teams often spontaneously bring up the work carried out by those police officers as being poles apart from their own. They can't imagine working there because of the "special nature" of the matters these units handle. They involve intimacy and sex, making it difficult to maintain the crucial divide between the private and the professional spheres. Although sex and intimacy are omnipresent in the everyday relations between officers - particularly in those units specializing in the use of force - they are only mentioned in jest and contribute to asserting officers' virile masculinity. For the officers who work in the mours and mineurs units, on the contrary, it is precisely the special nature of their work that legitimizes them and provides a space to assert unique professional skills such as listening and empathy with victims. Yet these are precisely the skills which are discredited in most other divisions, particularly because they provide no scope for the display of masculinity and are therefore relegated to the female end of policing activity. 
$<$ DISP-QUOTE $>$ You won't find more humane people than the officers in this team ... They know how to listen, how to change their tone of voice ... It's one of those jobs where psychology is really important.

$<$ ATTRIB $>$ (Deputy chief sergeant, Brigade des mœurs, 18 July 2013) $</$ ATTRIB $></$ DISP-QUOTE $>$ This quote illustrates how gender norms guiding street policing, as described earlier, are set aside or even challenged by the teams who specialize in the handling of sexual offenses. Indeed, in those teams, social and psychological skills (in particular with regard to the "rape victim," an archetypal figure regularly mentioned by officers of all divisions) are considered part of their professional know-how, one that transcends gender roles. It follows that the positions occupied by victims and perpetrators in the work culture are significantly different from those held by so-called "crime-fighting" teams. While the latter focus on the "perpetrator," actual or alleged, the former defines the usefulness of their mission by the support they provide to victims. In their work, quality listening, psychological support, and respect for due process are as important as obtaining criminal sanctions for the perpetrator.

$<$ DISP-QUOTE $>$ When we work on real cases, we are really useful to victims and it's so nice when you get a call, months after a case, from parents or children who call to say thank you, or who send a card. It's really important, that feeling that you're helping people to rebuild their lives, it's truly satisfying.

$<$ ATTRIB $>$ (Male officer, Brigade des mœurs, 02 July 2014) $</$ ATTRIB $></$ DISP-

QUOTE>

In other words, emotions and feelings that are shunned in other divisions, are elevated to the rank of policing skills by the officers in these units. This is true not only in their relations with victims, but also in their interactions with suspects. ${ }^{13}$ Their relations with suspects do not revolve around the virile confrontations that are so dear to street policing units. Rather, they focus on a form of emotional work centered on empathy. Units handling sexual violence combine concern for victims and the importance of women, which, in street policing, are characteristically side-lined. However, this amounts to reproducing rather than challenging gender stereotypes that differentiate and essentialize "masculinity" and "femininity." This was confirmed by observations of the daily activities of those units. We saw in interviews with male suspects in sexual offence cases the prevalence of moral norms rooted in a heteronormative gender order. This called for responses by officers who see themselves tasked with the "educational correction" of suspects. 
$<$ DISP-QUOTE $>$ You know what, when you get out of here, you're going to remember my face and you're going to do me a favor, when you next meet a girl who's coming onto you, you're going to be a man. You've got to be smart enough to know if she wants it or not. It doesn't mean she's going to give you a blowjob after ten minutes.

$<$ ATTRIB $>$ (Male officer interviewing a 14-year-old suspected of sexual assault on a 17-year-old minor, Brigade des mineurs, 11 February 2014) $</$ ATTRIB $></$ DISP-

Though the aim is to impart in "sexual deviants" values that place respect for women at the heart of the educational process, the message underlying these warnings reaffirms a differentiated attitude of men and women toward sexuality. It is women's presumed taste for seduction as well as their characteristic inconsistency that makes it difficult for men to control their sexual desires:

$<$ DISP-QUOTE $>$ That's what girls are like. They'll say yes five times and no the sixth, you've just got to know how to listen ...

$<$ ATTRIB $>$ (Debriefing after questioning, Brigade des mineurs, 11 February 2014) $</$ ATTRIB $></$ DISP-QUOTE $>$

\section{$<$ HEAD $1><$ TITLE $>$ Conclusion $</$ TITLE $></$ HEAD $1>$}

This ethnographic study by a two-person male/female team heavily underscores the prevalence of gender norms in professional hierarchies. These are apparent in subordinate relationships within the institution, in the organization of professional skills, and as a principle for ranking target populations. Despite the historic process of the institution's feminization, gender dictates and taboos remain strongly rooted in policing. Women maneuver in an institution where the dominant gender identity is that of the virile male. As illustrated by examples of the teams specialized in crime-fighting and in sexual offences, this gendered norm can fluctuate within the institution. Gender, nevertheless, acts as an organizing principle which contributes to the creation of hierarchies inside the policing profession, and to their selection of suspects and assignments (Mainsant 2012). From the broader perspective of public prosecution, it would seem that this "sexually differentiated nature of the handling of illegal activities" (Cardi 2009, p. 1) by the policing institution could shed light on other fields of study, such as the underrepresentation of women in the criminal justice system more generally (Vuattoux 2014). Most importantly, the forms of masculinity conveyed by the institution and the virile reputation of the policing profession could be studied in light of the difficulty the French police are having in evolving beyond their basic function of repression. The relatively recent incursion of French 
social scientists into the study of the gendered realities of police work thus lays the groundwork for future research. This research should further question the performative effects of gendered attributions, in parallel with other forms of hierarchy - particularly sexual, social, and ethnoracial - that shape both police handling of the public and the professional codes in force within the organization. $</$ BODY $>$

$<\mathrm{BACK}>$

\section{$<$ REF-LIST $><$ TITLE $>$ References $</$ TITLE $>$}

Acker, J. 1990. Hierarchies, jobs, bodies: A theory of gendered organizations. Gender and Society 4: 139-158.

Astor, S., and Roché, S. 2013. Enquête 'POLIS-autorité' Premiers résultats: Rapport à l'attention de l'Éducation Nationale. Grenoble: PACTE - Laboratoire de sciences sociales. Bereni, L., Chauvin, S., Jaunait, A., and Revillard, A. 2008. Introduction aux études sur le genre. Bruxelles: De Boeck.

Bereni, L., and Jacquemart, A. 2018. Diriger comme un homme moderne: Les élites masculines de l'administration française face à la norme d'égalité des sexes. Actes de la recherche en sciences sociales 223: 72-87.

Blanchard, E. 2008. Le mauvais genre des Algériens: des hommes sans femme face au virilisme policier dans le Paris d'après-guerre. Clio: histoire, femmes et sociétés 27: 209-224. Blanchard, E. 2012. Des Algériens dans le 'Paris Gay': Frontières raciales et sexualités entre hommes sous le regard policier. Pp. 157-174 in P. Rygiel (Dir.) Politique et administration du genre en migration. Mondes Atlantiques, XIXe-XXe siècles. Paris: AHI/Publibook. Boussard, V., Loriol, M., and Caroly, S. 2007. Une féminisation sur fonds de segmentation professionnelle genrée: le cas des policières en commissariat. Sociologies pratiques 1: 75-88. Brown, J. 2007. From cult of masculinity to smart macho: Gender perspectives on police occupational culture. Sociology of Crime Law and Deviance 8: 205-226.

Brown, J., and Heidensohn, F. 2000. Gender and policing: Comparative perspectives. Basingstoke: Macmillan.

Burke, M. 1993. Coming out of the blue: British police officers talk about their lives in "the job" as lesbians, gays and bisexuals. New York: Cassell Publishing.

Cardi, C. 2009. Le féminin maternel ou la question du traitement pénal des femmes. Pouvoirs 1: 75-86.

Clair, I. 2013. Pourquoi penser la sexualité pour penser le genre en sociologie? Retour sur quarante ans de réticences. Cahiers du Genre 1: 93-120. 
Clair, I. 2016. La sexualité dans la relation d'enquête: Décryptage d'un tabou méthodologique. Revue française de sociologie 57: 45-70.

Darley, M., and Gauthier, J. 2014. Une virilité interpellée? En quête de genre au commissariat. Genèses 4: 67-86.

Darley, M., and Gauthier, J. 2018. Le travail policier face à la réforme: Une ethnographie de la mise en œuvre des 'Zones de Sécurité Prioritaires'. Politix 4: 59-84.

Défenseur des droits. 2017. Enquête sur l'accès aux droits. Volume 1-Relations police/populations: le cas des contrôles d'identité. Paris.

Fassin, D. 2002. L'invention française de la discrimination. Revue française de science politique 52: 403-423.

Fassin, D. 2011. La force de l'ordre: Une anthropologie de la police des quartiers. Paris: Seuil.

Fielding, N. 1994. Cop canteen culture. Pp. 46-63 in T. Newburn and E. Stanko (Eds.) Just boys doing the business: Men, masculinity and crime. London: Routledge.

Gauthier, J. 2012. Origines contrôlées: La police à l'épreuve de la question minoritaire à Paris et à Berlin. Thèse de sociologie à l'Université de Versailles-Saint-Quentin-enYvelines.

Gauthier, J., and Schlagdenhauffen, R. 2019a. Les sexualités 'contre-nature' face à la justice pénale: Une analyse des condamnations pour 'homosexualité' en France (1945-1982).

Déviance et société, à paraître.

Gauthier, J., and Schlagdenhauffen, R. 2019b. Facing normative heterosexuality: The case of LGBT police officers in France. Paper presented at the international conference Police, justice et homosexualités. Regards sociologiques, historiques et comparatifs. Paris: Ecole des Hautes Etudes en Sciences Sociales.

Gautier, F. 2018. Une 'résistible' féminisation? Le recrutement des gardiennes de la paix. Travail, genre et sociétés 1: 159-173.

Guenot, M. 2018. Le crime ne paie pas: Les Groupes d'intervention Régionaux de la Police judiciaire. Sociologie politique de la construction d'une institution au succès improbable. Paris: Thèse de doctorat, Université Paris 8.

Heidensohn, F. 1992. Women in control? The role of women in law enforcement. Oxford: Oxford University Press.

Heidensohn, F. 2008. Gender and policing. Pp. 642-665 in T. Newburn (Ed.) Handbook of policing. Cullompton: Willan.

Hunt, J. 1990. The logic of sexism among police. Women \& Criminal Justice 1: 3-30. 
Jaouen, R. 2017. L'inspecteur et l'inverti: La police face aux sexualités masculines à Paris 1919-1940. Rennes: Presses Universitaires de Rennes.

Jobard, F. 2006. Police, justice et discriminations raciales. Pp. 211-229 in E. Fassin and D. Fassin (Eds.) De la question sociale à la question raciale? Représenter la société française. Paris: La Découverte.

Jobard, F., and de Maillard, J. 2015. Sociologie de la police: Politiques, organisations, réformes. Paris: Armand Colin.

Jobard, F., Lévy, R., Lamberth, J., and Névanen, S. 2012. Mesurer les discriminations selon l'apparence: Une analyse des contrôles d'identité à Paris. Population 67: 423-451.

Le Feuvre, N., Bataille, P., and Morend, L. 2013. La visibilité du genre dans des revues de sociologie du travail: Comparaisons France et Grande-Bretagne (1987-2012). Cahiers du Genre 1: 121-150.

Lemaire, É. 2008. Spécialisation et distinction dans un commissariat de police: Ethnographie d'une institution segmentaire. Sociétés contemporaines 72: 59-79.

Mainsant, G. 2008. L'Etat en action: classements et hiérarchies dans les investigations policières en matière de proxénétisme. Sociétés contemporaines 4: 37-57.

Mainsant, G. 2012. L'État et les illégalismes sexuels. Ethnographie et sociohistoire du contrôle policier de la prostitution à Paris. Paris: Thèse de doctorat, Ecole des Hautes Etudes en Sciences Sociales.

Mainsant, G. 2014. Comment la 'Mondaine' construit-elle ses populations cibles? Le genre des pratiques policières et la gestion des illégalismes sexuels. Genèses 4: 8-25.

Marry, C., Bereni, L., Jacquemart, A., Pochic, S., and Revillard, A. 2017. Le plafond de verre et l'État. La construction des inégalités de genre dans la fonction publique. Paris: Armand Colin.

Ministère de 1'Intérieur. 2017. Bilan social 2017: Rapport de situation comparée relatif à l'égalité professionnelle entre les femmes et les hommes. Paris.

Monjardet, D. 1996. Ce que fait la police, sociologie de la force publique. Paris: La Découverte.

Morelle, M. 2017. La fabrique de territoires policiers: Des pratiques professionnelles en débat dans une commune francilienne. Droit et Société 3: 469-484.

Pérona, O. 2017. La difficile mise en œuvre d'une politique du genre par l'institution policière: le cas des viols conjugaux. Champ pénal/Penal field 14.

[https://journals.openedition.org/champpenal/9546] 
Pierce, J. L. 2003. Les émotions au travail: le cas des assistantes juridiques. Travailler 1: 5172.

Proteau, L., and Pruvost, G. 2008. Se distinguer dans les métiers d'ordre (armée, police, prison, sécurité privée). Sociétés contemporaines 4: 7-13.

Pruvost, G. 2007a. Profession: policier, Sexe: féminin. Paris: Maison des Sciences de l'Homme.

Pruvost, G. 2007b. Enquêter sur les policiers: Entre devoir de réserve, héroïsation et accès au monde privé. Terrain 48: 130-148.

Pruvost, G. 2008. De la 'sergote' à la femme flic: Une autre histoire de l'institution policière, 1935-2005. Paris: La Découverte.

Reiner, R. 2000. The politics of police. Oxford: Oxford University Press.

Rubin, G. 1975. The traffic in women: Notes on the "political economy" of sex. Pp. 157-210 in R. Reiter (Ed.) Toward an anthropology of women. New York: Monthly Review Press. Silvestri, M. 2003. Women in charge: Policing, gender and leadership. Cullompton: Willan Publishing.

Tamagne, F. 2000. Histoire de l'homosexualité en Europe: Berlin, Londres, Paris. Paris: Seuil.

Vuattoux, A. 2014. Adolescents, adolescentes face à la justice pénale. Genèses 4: 47-66. Waddington, P. A. 1999. Police (canteen) sub-culture: An appreciation. British Journal of Criminology 39: 287-309.

Westmarland, L. 2001. Gender and policing. Cullompton: Willan Publishing.</REF-LIST> $</ \mathrm{BACK}>$

\section{$</$ BOOK-PART $>$}

\footnotetext{
1 This status can nevertheless be questioned, as we see in a shocking scene where an investigator asks a young woman to apologise to her alleged rapist for the trouble she caused in reporting him.

2 Interview, male officer, Compagnie de sécurisation, 16 November 2013.

3 In 2010, the Brigades Spécialisées de Terrain (BST) took the place of the Unités territoriales de quartier (Uteq) or Neighbourhood Territorial Units, which were created in 2008. As of 2012, they were sent specifically into the zones de sécurité prioritaires, or high priority security areas, created under the socialist government in neighborhoods said to be sensitive. See Darley and Gauthier (2018).

4 The Compagnies de sécurisation (CS), created in 2003, are specialized urban crime-fighting units. Reintroduced in 2008 in order to strengthen security in the capital and in the sensitive neighborhoods, their remit is to intervene firstly in high-risk events or instances of urban violence.

5 The Brigades Anti-Criminalité (BAC) first appeared in the early 1970s in Paris, before spreading to other medium and large towns in the 1990s. Crime squad officers usually operate in plain clothes, in unmarked vehicles and specialize in high-risk operations in urban areas, in particular in those neighborhoods said to be "sensitive" because of the concentration of delinquent behavior there. See Fassin (2011).

${ }^{6}$ Ministry of the Interior 2017. This report compares professional equality between men and women.

7 These are the Brigade anti-criminalité (BAC), Brigade spécialisée de terrain (BST), and Compagnie de sécurisation (CS).

${ }^{8}$ At the time of this study of the Compagnies de Sécurisation, women accounted for three out of 50 officers, in the crime squad two out of 42 , and in the BST three out of 30 .
} 
${ }^{9}$ Quite significantly, the women we interviewed within departments specialised in the use of force all presented different characteristics typically associated with femininity (long hair, make-up, jewellery).

10 Field journal, Compagnie de Sécurisation.

11 ELIPSS/PREFACE survey carried out in 2017 on a sample of 2,900 people in mainland France, within the framework of the PROFET ("Ordinary Practices and Representations in the Face of the State") program, funded by the national research agency and coordinated by Alexis Spire (CNRS-IRIS).

12 The Brigade des mineurs also handles sexual assaults on adults who were minors at the time of the assault.

${ }^{13}$ A recent study shows that police empathy can vary depending on the status of the victims, however; see Pérona (2017). 